\title{
Blood Parameter Analysis and Morphological Alterations as Biomarkers on the Health of Hoplias malabaricus and Geophagus brasiliensis
}

\author{
Silvia Romão ${ }^{1 *}$, Lucélia Donatti ${ }^{2}$, Matheus O. Freitas ${ }^{1}$, Josiane Teixeira ${ }^{1}$ and Josiana \\ Kusma $^{1}$ \\ ${ }^{I}$ Universidade Tuiuti do Paraná; Faculdades de Ciências Biológicas e de Saúde; Marcelino Champagnat, \\ 508; Curitiba - PR - Brasil. ${ }^{2}$ Universidade Federal do Paraná; Departamento de Biologia Celular; C. P. 19031; \\ 81531-970; Curitiba - PR - Brasil
}

\begin{abstract}
This study aimed to assess the influence of the environment on fish health. Samples of Hoplias malabaricus and Geophagus brasiliensis, were collected from three different environments: area I was urban and areas II and III were rural. Analyses of red blood cell count, microhematocrit, hemoglobin concentration, white blood cell count and differential white cell count in blood smear were carried out. Mean corpuscular volume and mean corpuscular hemoglobin concentration were calculated. To analyze morphological alterations, gills, liver, kidney and gonads were submitted to routine histological processing. Individuals collected from area III had slightly lower blood indices than collected from area I. Severe kidney changes, degeneration of and crystallization within kidney tubules were observed. In area I, crystallization was observed in 92\% of the specimens of G. brasiliensis. These results suggested that such alterations were related with poor water circulation in the place.
\end{abstract}

Key words: Fish, bioindicators, biomarkers, morphological alterations, hematology

\section{INTRODUCTION}

Fish populations are susceptible to environmental impacts caused by the introduction of exotic species, industrial wastes, oil spills, pesticides and other agents that directly affect ecology and the survival of species. Methods for diagnosing and monitoring the quality of life of these populations ought to be used. Toxic effects of organic products regarded as pollutants upon the biochemical and physiological systems of an organism can be assessed through the study of cellular and subcellular morphological alterations (Meyer et al., 1998). The analysis of morphological changes is an efficient tool for diagnosing and identifying the physiological consequences of sublethal contamination (Mallat, 1985; Roberts, 1989; Fanta et al., 2003; Boeger et al., 2003). Organs for diagnosis are chosen according to the functions they perform. Because the gills are in close contact with contaminated water, toxic substances cause damage to their structure and function (Mallat, 1985; Fanta et al., 2003; Boeger et al., 2003); the liver is exposed to toxic substances because it is the organ in charge of biotransforming them (Rodrigues and Fanta, 1998; Fanta et al., 2003; Boeger et al., 2003); the kidneys are exposed during the excretion process (Landolt, 1975; Roberts, 1989; Pavanelli et al., 2002). The gonads

\footnotetext{
${ }^{*}$ Author for correspondence
} 
should also be considered, due to their role in the maintenance of the population. Another biomarker used in diagnoses is the hematological profile. This can be used to study the normal cell pattern (morphology and percentages) ( Garcia-Navarro, 1994; Ranzani-Paiva et al., 1999), to study alterations in blood parameters revealing lesions in other organs or tissues (Garcia-Navarro, 1994), or to help breeding, given that changes in the hematological profile may indicate infestations and infections or even environmental changes (Ranzani-Paiva et al., 1999). According to Serpunin and Likhatchyova (1998), the blood parameters of a fish species are true indicators of the state of health of the organism, and white blood cell tests play an important role in the monitoring of contaminated surface waters (Trombickij and Gorbunenko, 1993 apud Modra et al., 1998).

Hoplias malabaricus belongs to the family Erythrinidae and is widespread throughout South America, except for the transandine area and Patagonian rivers (Nakatani et al., 2001). This species is markedly carnivorous, feeding mostly on fish. It lives in still water environments and is very resistant to low oxygen levels (Silvano et al., 2001). Geophagus brasiliensis, a species of the family Cichlidae, has a broad geographical distribution, from the state of Amapá in Brazil to the River de la Plata. With a varied diet, it is considered omnivorous (Andreata and Tenório, 1997). The family is characterized by living in still waters, such as marginal lagoons and backwaters along riverbanks (Silvano et al., 2001).

This study aimed to assess the influence of the environment on fish health. The species Hoplias malabaricus and Geophagus brasiliensis were used as bioindicators; the hematological profile and morphological alterations in gills, liver, kidney and gonads were used as biomarkers.

\section{METHODS}

\section{Specimen Collection}

The representative fish from Area I (urban) were collected out of a lake in the urban area of Curitiba (PR), in the Shaffer campus of Universidade Tuiuti do Paraná. The fish from Area II (rural) were collected at a fish breeding site established near the place from which the water used springs and far from the urban region, apparently without the influence of pollutants. Area III (rural) corresponded to a farm lake in the city of São José dos Pinhais, in the Curitiba Metropolitan Region. Samples were collected from March 2002 to April 2003. The animals were captured with casting nets and fishing rods.

From area I, 24 specimens of G. brasiliensis (total length $11.5-21.5 \mathrm{~cm}$ ) and 9 specimens of $H$. malabaricus (total length $29.0-37.5 \mathrm{~cm}$ ) were collected. From area II, 7 specimens of $G$. brasiliensis (total length 9.0-19.5 cm) and 2 specimens of $H$. malabaricus (total length 26.2$27.0 \mathrm{~cm}$ ) were collected. From area III, 5 specimens of $G$. brasiliensis (total length 10.5$17.0 \mathrm{~cm}$ ) were collected.

\section{Blood Sampling and Analysis}

Blood analyses were carried out only on specimens of $G$. brasiliensis collected from areas I and III. Blood was collected by caudal vein puncture with heparinized disposable syringes. Analyses of red blood cell count (per $\mu \mathrm{L}$ of blood), microhematocrit, hemoglobin concentration, white blood cell count and differential white cell count in blood smear stained with May GrünwaldGiemsa were carried out. Erythrocyte indices such as mean corpuscular volume (MCV) and mean corpuscular hemoglobin concentration (MCHC) were calculated. All steps followed the methodology described in Garcia-Navarro (1994).

\section{Tissue Sampling and Processing for Histological Analysis}

The animals were sacrificed by severing the spinal cord. Gills, liver, kidney and gonads were collected, fixed for 24 hours in FAA (Beçak and Paulete, 1976), and then transferred to $70 \%$ alcohol before they were submitted to routine histological processing (Beçak and Paulete, 1976). This processing consisted of organ dehydration in a graded alcohol series, clearing in xylene, infiltration and embedding in paraffin. The embedded organs were sectioned at 4 to $6 \mu \mathrm{m}$ thickness on a Minnot microtome and stained with Harris' hematoxilin and eosin (Horobin and Bancroft, 1998). Images were captured using a Leica DMLS microscope (with the Leica QWin image analysis software suite) and an Olympus PM-10AD photomicroscope.

The gills were examined for the most frequent alterations: lifting of the respiratory epithelium, hypertrophy, hyperplasia, fusion of respiratory lamellae, congestion, vacuolation, hemorrhage, destructuring of the secondary lamellae and 
increase in mucus secretion. These changes were identified according to Mallat (1985), Roberts (1989), Fanta et al. (2003) and Boeger et al. (2003). Liver changes (leukocyte infiltration, fatty degeneration, hydropic degeneration, eosinophilic hepatocytes, necrosis and congestion) were analyzed according to the descriptions by Roberts (1989) and Brasileiro-Filho (1994). Kidney changes were analyzed according to the descriptions by Roberts (1989); we looked for alterations such as tubular degeneration, necrosis and crystallization. Gonad changes, namely, atretic follicles were analised, as described by Vazzoler (1996) e Reichenbach-Klinke1973).

\section{Impact Index}

All specimens were examined for cellular alterations in gills, liver, kidney and gonads. The absence and presence of each of these changes were converted respectively into numbers 0 and 1 . The impact on an organ is the sum of alterations present in the analyzed individual. The impact index of an organ in the studied group is the average of individual impacts.

\section{RESULTS}

No morphological alterations were observed at macroscopic levels in the samples.

\section{Hematologic Profile Analyses}

Blood pattern analyses of G. brasiliensis showed that there was little variation between individuals collected from the areas I and III (Table 1), which was not significant. Leukocytes in low percentages were found in the two environments, with an average of $0.4 \% \pm 0.2$. Monocytes, neutrophils, special granulocytic cells, lymphocytes and immature cells were the leukocytes found. Immature cells were more frequent among individuals collected from the area III; lymphocytes were the most abundant cells among individuals collected from the area I.

\section{Morphological Analyses - Gills}

Figs. 1A and 1B show the gill arch of the studied species, a gill arch peculiar to teleost fish. The following alterations were not observed: hypertrophy, fusion of respiratory lamellae, vacuolation, hemorrhage and destructuring of the secondary lamellae.

$\underline{\text { Table } 1 \text { - Blood pattern analyses of G. brasiliensis collected in areas I and III }}$

\begin{tabular}{cccccc}
\hline & Micro hematocrit & $\mathbf{R B C}$ count $\left(\mathbf{1 0}^{\mathbf{3}}\right)$ & {$[\mathbf{H b}]$} & MCV & MCHC \\
\hline Area I & $28.5 \pm 5(\mathrm{n}=13)$ & $2,246 \pm 712.6(\mathrm{n}=12)$ & $6.35 \pm 1.13(\mathrm{n}=9)$ & $136.48 \pm 43.43(\mathrm{n}=11)$ & $25.09 \pm 4.18(\mathrm{n}=9)$ \\
Area III & $21 \pm 7.9(\mathrm{n}=3)$ & $1,420 \pm 558.6(\mathrm{n}=5)$ & $5 \pm 0.6(\mathrm{n}=5)$ & $107.11 \pm 47.9(\mathrm{n}=4)$ & $24.9 \pm 5.1(\mathrm{n}=4)$ \\
\hline
\end{tabular}

Lifting of the respiratory epithelium was found in animals collected in all three environments (Figure 1C). In area I, $80 \%$ of G. Brasiliensis and $30 \%$ of H. malabaricus presented this lifting; 71.4 and $60 \%$ of G. brasiliensis presented this alteration in areas II and III, respectively; $33 \%$ of $\mathrm{H}$. malabaricus presented it in area II. Cell proliferation (hyperplasia) in the respiratory epithelium (Fig 1D) was the change observed only in $14.3 \%$ of G. brasiliensis collected in area II. The impact index of gills (from 1 to 3 ) for $\mathrm{H}$. malabaricus was 0.3 both in areas I and III. For G. brasiliensis, these were 0.8 (area I), 0.86 (area II), and 0.6 (area III).

\section{Morphological Analyses - Liver}

The normal liver parenchyma of both species had the pattern teleost fish, in the which polygonal cells, similar to liver cells, were arranged in irregular cell cords separated by sinusoids; it was not possible to observe bile canaliculi. The liver of G. brasiliensis presented melanomacrophage centers and infiltration by pancreatic tissue (Fig 2A). Fatty degeneration, hydropic degeneration, eosinophilic hepatocytes were not observed, but leukocyte infiltration (Fig 2B), congestion (Fig 2C) and necrosis (Fig 2D) were present. Leukocyte infiltration in the liver parenchyma was found in $13 \%$ of $\mathrm{G}$. brasiliensis and in $45 \%$ of $\mathrm{H}$. malabaricus collected in area I; it was found also 
in $28.5 \%$ of $\mathrm{G}$. brasiliensis and in $66 \%$ of $\mathrm{H}$. malabaricus collected in area II. Congestion was found in $13 \%$ of $\mathrm{G}$. brasiliensis and in $27 \%$ of $\mathrm{H}$. malabaricus collected in area I; it was found also in $33 \%$ of G. brasiliensis collected in area II and in $100 \%$ of $\mathrm{H}$. malabaricus collected in area III. Liver cell necrosis was found in $21 \%$ of G. brasiliensis and in $27 \%$ of $\mathrm{H}$. malabaricus collected in area I. The impact index of the liver (from 1 to 3 ) for $\mathrm{H}$. malabaricus was 1.0 in area I and 1.2 in area II. For G. brasiliensis these were 0.46 (area I), 0.29 (area II), and 1.0 (area III).
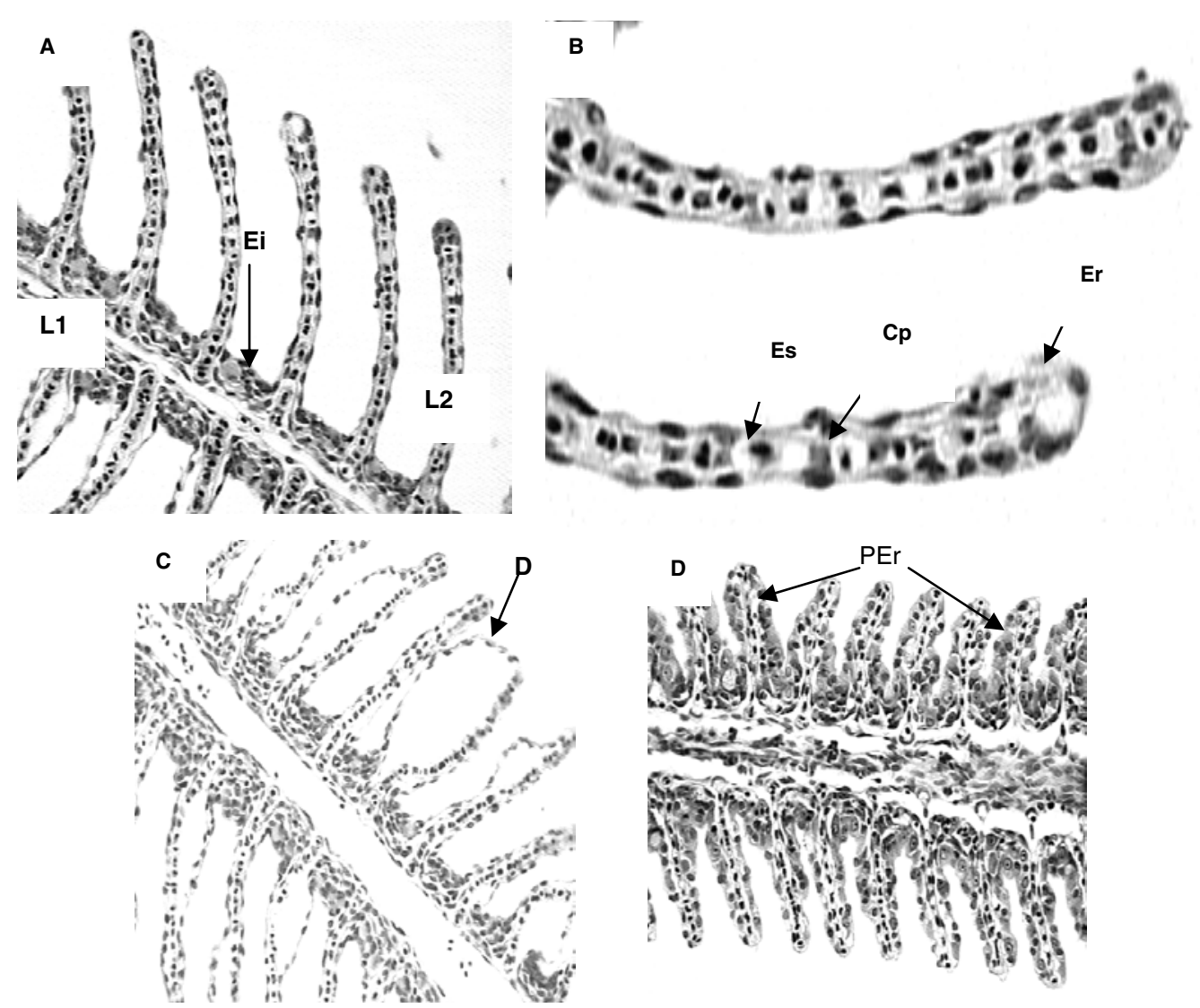

Figure 1 - Normal histological pattern and morphological alterations in gills of G. brasiliensis. A Normal histological pattern of the gill filament, indicating primary lamella (L1), secondary lamella (L2) and interlamellar epithelium (Ei) (H.E. - 400x). B - Detail of the secondary lamella, indicating respiratory epithelium (Er), pillar cell $(\mathrm{Cp})$ and lacuna or capillary lumen (Es) (H.E - 1000x). C - Gill filament with lifting of the respiratory epithelium (Dr) (H.E. - 400x). D - Hyperplasia in the respiratory epithelium (PEr) (H.E. 400x).

\section{Morphological Analyses - Kidney}

The kidneys of the species examined had a pattern similar to that found in other vertebrates. They were composed of nephrons consisting mainly of a Malpighian corpuscle, of a tubule, and of a collecting duct system to which the filtrate was led. The Malpighian corpuscle had a capillary network that forms the glomerulus (Fig 3A). Necrosis and Malpighian corpuscle alterations were not observed, but tubular degeneration (Fig 3B) and crystallization within tubule lumens (Fig 3C) were present. Tubular degeneration was found in $64 \%$ of $\mathrm{G}$. brasiliensis and in $78 \%$ of $\mathrm{H}$. malabaricus collected in area I; it was found in $85.7 \%$ of $G$. brasiliensis and in $100 \%$ of $H$. malabaricus collected in area II. Crystallization within tubule lumens was found in $92 \%$ of $G$. brasiliensis and in $11 \%$ of $H$. malabaricus collected in area $\mathrm{I}$; this change was not observed among individuals collected in areas II and III. 

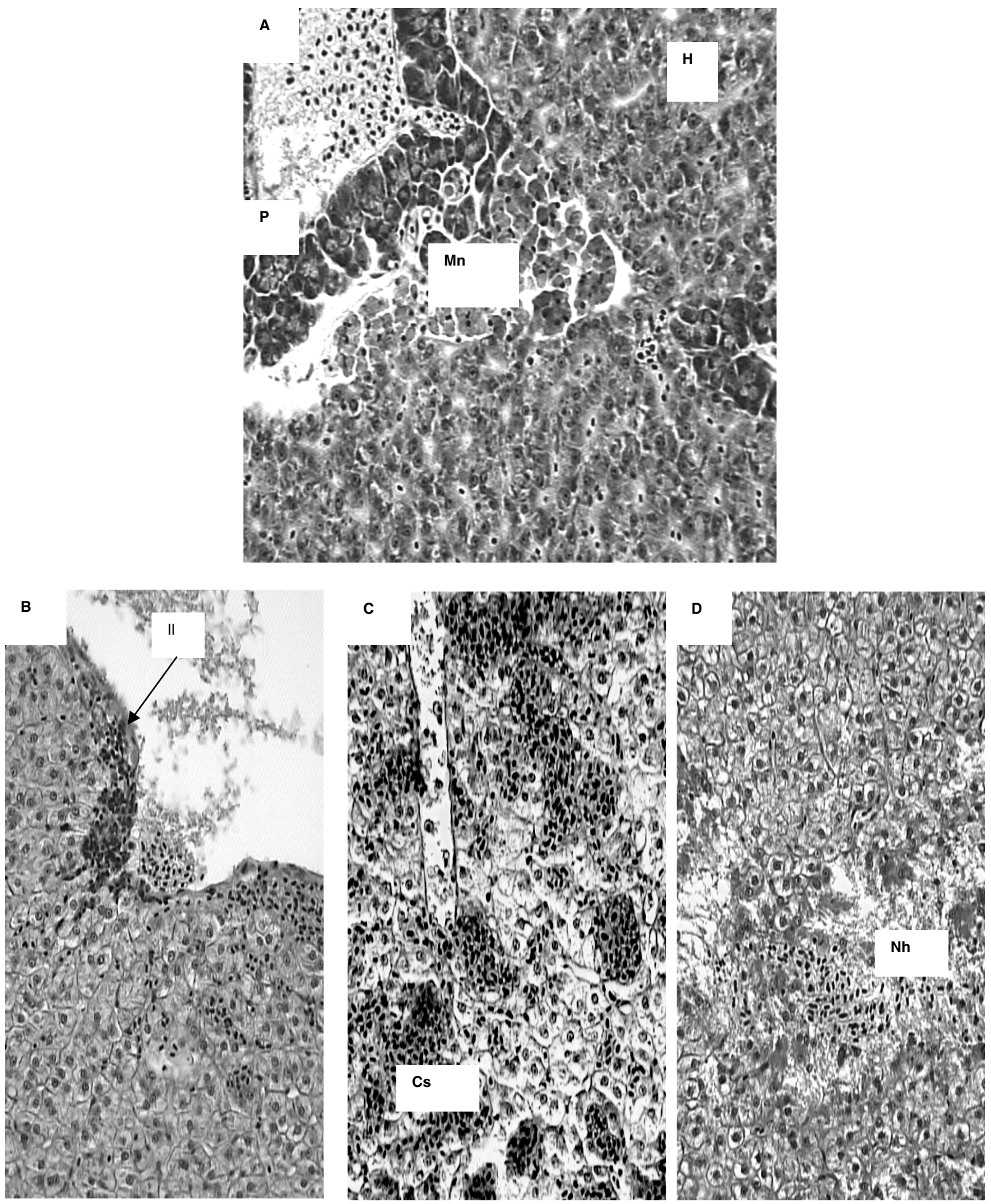

Figure 02 - Normal histological pattern and morphological alterations in liver of G. brasiliensis. A Liver $(\mathrm{H})$ and Pancreas $(\mathrm{P})$; a melanomacrophage $(\mathrm{Mn})$ of $G$. brasiliensis (H.E.- 400x). B - Liver of $G$. brasiliensis with a focus of leukocyte infiltration (Il) (H.E.- 400x). C Liver of H. malabaricus with a focus of blood congestion (Cs) (H.E.- 400x). D - Liver of G. brasiliensis with a focus of hepatocyte necrosis (Nh) (H.E.- 400x). 

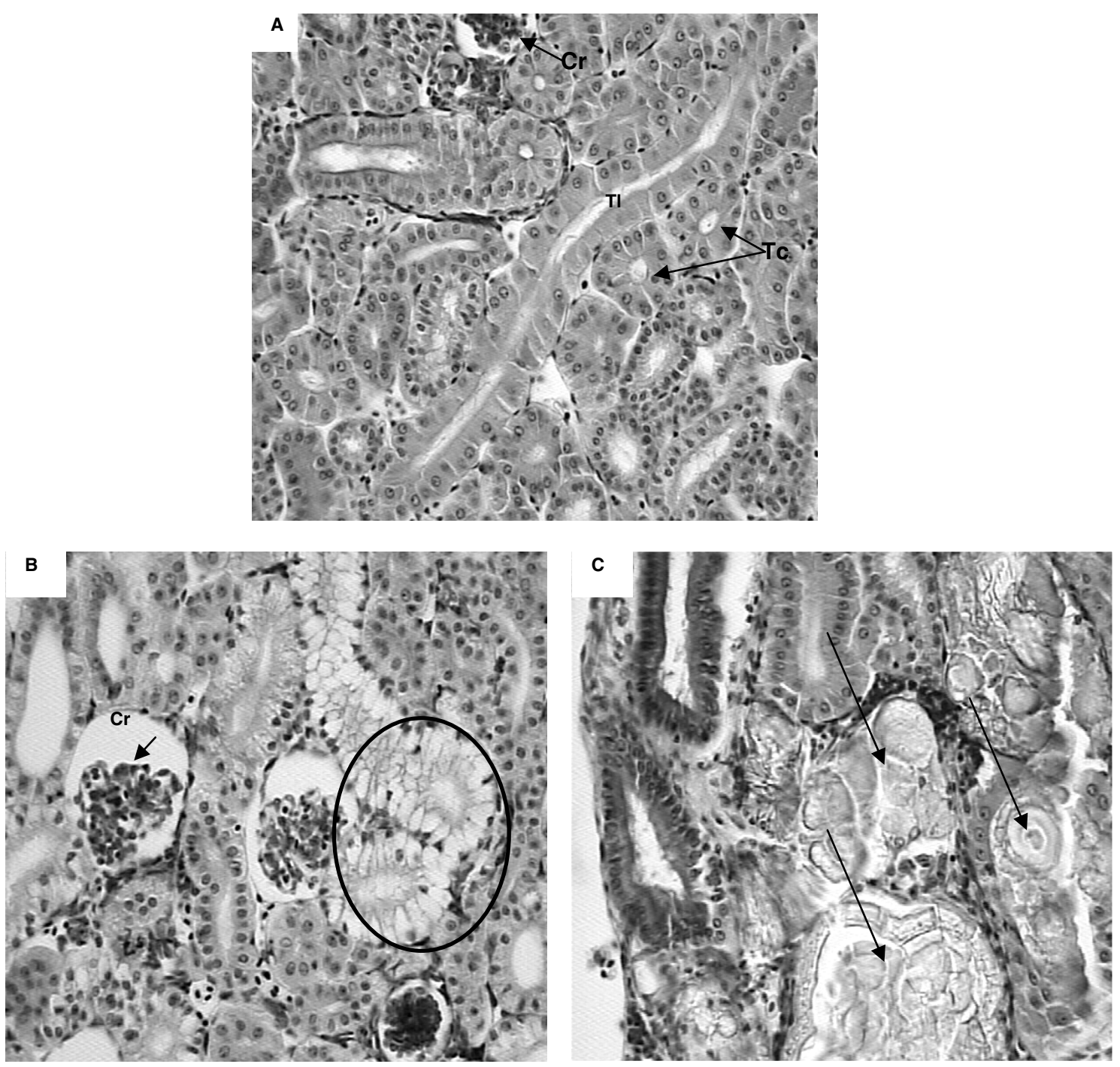

Figure 3 - Normal histological pattern and morphological alterations in kidney of G. brasiliensis. A Normal histological pattern of the kidney, with Malpighian corpuscle $(\mathrm{Cr})$ and kidney tubules in longitudinal (Tl) and transverse sections (Tc) (H.E.- 400x). B - Kidney with Malpighian corpuscle (Cr), containing one glomerulus (arrow) and degenerating kidney tubules (highlighted) (H.E.- 400x). C - Kidney with crystallization within tubule lumens (arrows) (H.E.- 400x).

The impact index of the kidney (from 1 to 3 ) for $H$. malabaricus was 0.89 in area I and 1.0 in area II. For G. brasiliensis, these were 1.56 (area I), 0.86 (area II), and 1.0 (area III).

\section{Gonads}

Variations in the stages of gonad maturation were observed among individuals collected in different seasons of the year. The two studied areas had similar variations. No atretic follicles were observed in the gonads of the animals examined.

\section{DISCUSSION}

Studies suggest that the blood indices of a fish species suffer changes related to variations in the aquatic environment (Serpunin and Likhatchyova, 1998). Variations were found in the hematological indices of specimens of G. brasiliensis collected from the areas I and III. Such variations common among other species, such as Prochilodus scrofa, Piractus mesopotamicus, Colossoma macropomum (Ranzani-Paiva et al., 1999), Mugil platanus (Ranzani-Paiva, 1995), and others that 
either are economically important or may serve as bioindicators (Modra, et al., 1998). Hematological indices observed among individuals collected from the area III (rural) were lower than those observed among individuals collected from the area I (urban). It could be suggested that this variation in hematological indices could be related to a higher physiological demand among individuals collected from an urban environment and to adaptive mechanisms to the environment, especially to poor water circulation.

The leukocyte series, eosinophil and basophil granulocytes were not found in the studied specimens. This indicated an extremely low concentration of these cell types. Modra et al. (1998) observed low concentration of eosinophils and the absence of basophils in several fish species, such as Cyprinus carpio, Tinca tinca, Siluris glanis and Oncorhinchus mykiss. According to Ranzani-Paiva (1995), it is difficult to preserve basophils, and this is the main reason why basophils are difficult to identify in fish blood. However, by preserving cells from the blood smear, basophils were identified in the blood of $H$. malabaricus. Nucleated erythrocytes make white cell count difficult, so that one frequently resorts to the leukocyte percentages in blood smear as a quantifying method. In both environments, low percentages of leukocytes were found, and this indicated a peculiar trait of the species. High leukocyte numbers could be related to parasitism (high concentration of eosinophils) or to bacterial infection (lymphocytes, monocytes, and neutrophils) (Ranzani-Paiva et al., 1999).

Morphological alteration analyses in gills, liver, kidney and gonads of $G$. brasiliensis and $H$. malabaricus collected in different environments showed that fish populations were in low percentages subject to the onset of pathologies. This was confirmed by the fact that the impact indices for gill and liver alterations within each species and the impact index for kidney alterations in $H$. malabaricus were similar. However, severe kidney changes were identified, mostly among $G$. brasiliensis: crystallization within kidney tubules was observed in $92 \%$ of the specimens collected in area I, but was not observed in the other environments. This condition indicated that the environment exerted a negative influence on the excretory systems of these animals. According to Landolt (1975), the most frequent renal condition among freshwater and seawater fish in intensive aquaculture systems is nephrolithiasis or urolithiasis. High carbon dioxide levels in water and/or high calcium and magnesium levels in diet are the most frequent predisposing agents to this condition (Pavanelli et al., 2002; Roberts, 1989). The precipitation of calcium salts within the tubules and collecting ducts, dilation of these ducts, granuloma formation, contractin of the glomerular tuft, thickening of the glomerular membrane and periglomerular fibrosis are the lesions observed in urolithiasis (Roberts, 1989). However, the results suggested that low levels of these conditions were presents in $G$. brasiliensis and $H$. Malabaricus collected from the area I, therefore the glomerular changes above cited were not observed. Other lesion observed was the tubular degeneration. This alteration apparently was restricted to the proximal region of the kidney tubules, not involving the glomerulus. A suggestion for this alteration could be its relation with specific functions of the proximal tubules such as excretion of divalent ions or reabsortion or secretion of molecules.

Poor water circulation was observed in area I, with the ensuing low oxygen level problems. Besides, according to Silvano et al., (2001), $H$. malabaricus was resistant to low-oxygen-level environments, and a low percentage $(11 \%)$ of individuals of this species suffered from this condition. G. brasiliensis was found in still water environments; therefore, it could be resistant to low oxygen levels. However, it was noticed that there were limits to this resistance, beyond which fish departed from homeostatic balance. The results indicated that $H$. malabaricus was better adapted to low-oxygen-level conditions.

\section{RESUMO}

Este trabalho teve como objetivo avaliar a influência do ambiente sobre a higidez dos peixes. Animais, das espécies Hoplias malabaricus e Geophagus brasiliensis foram coletados em três ambientes distintos, sendo ambiente I região urbana e ambientes II e III em região rural. Foram realizadas análises do número total de eritrócitos por microlitro de sangue, microhematócrito, taxa de hemoglobina, porcentagem de leucócito e contagem diferencial de leucócitos em extensão sanguínea. Calcularam-se os índices hematimétricos absolutos: volume corpuscular médio e concentração de hemoglobina corpuscular média. Para análises das alterações morfológicas, 
brânquias, fígado, gônadas e rim seguiram processamento histológico de rotina. Foram observados índices hematológicos ligeiramente menores em indivíduos coletados no ambiente III em relação aos animais coletados no ambiente I. As análises histológicas de brânquias, fígado e gônadas das espécies $G$. brasiliensis $e \quad H$. malabaricus demonstraram alterações morfológicas em porcentagens baixas. Foram identificas alterações internas nos rins, sendo representadas por degeneração e cristalização no interior dos túbulos renais. Em $92 \%$ dos indivíduos de G. brasiliensis, coletados no ambiente I, foi observado cristalizações no interior de túbulos. Sugere-se que tais alterações estejam relacionadas com a baixa circulação de água no local.

\section{REFERENCES}

Andreata, J. V. and Tenório, M. M. B. (1997), Aspectos da alimentação de Geophagus brasiliensis (Quoy and Gaimard, 1824) da lagoa Rodrigo de Freitas, Rio de Janeiro, Brasil. Acta Biológica Leopoldensia, 19 : (2), 185-195.

Beçak, W. and Paulete, J. (1976). Técnicas de Citologia e Histologia. Rio de Janeiro: LTC. v. 1.

Boeger, W.; Ostrensky, A.; Guimarães, A. T. B. and Romão S. (2003), Histopathology as an approach to evaluate the effect of the oil spill on fishs of the rivers Saldanha, Barigui, and Iguaçu (Brazil). Proceedings of International oil Spill Conference, 2003.

Brasileiro Filho, G. (1994), Bogliolo Patologia. 5. ed. Rio de Janeiro: Guanabara Koogan. 1243 pp.

Landolt, M. (1975), Visceral granuloma and nephrocalcinosis of trout. In: Ribelin, W. E. and Migaki, G. (Ed.). The Pathology of Fishes. The University of Wisconsin Press. pp. 793-801.

Fanta, E.; Rios, F. S.; Romão, S.; Vianna, A.C.C. and Freiberger, S. (2003), Histopathology of fish Corydoras paleatus contaminated with sublethal levels of organophosphorus in water and food. Ecotoxicology and Environmental Safety, 54, 119-130.

Garcia-Navarro, C. E. K. (1994), Hematologia dos animais domésticos. In: Garcia-Navarro, C. E. K. And Pachaly, J. R. Manual de Hematologia Veterinária. Primeira edição, São Paulo: Varela. pp. 11-119.

Horobin and Bancroft (1998), Troubleshooting histology stains. Hong Kong: Pearson Professional Limited.

Mallat, J. (1985), Fish gill structural changes induced by toxicants and others irritants: A statistical review. Can. J. Fish. Aquat. Sci., 42, 630-648.
Meyers, M. S.; Johnson, L. L.; Hom, T.; Collien, T. K.; Stein, J. E. and Varanasi, U. (1998), Toxipathic Hepatic lesion in subadult English Sole (Pleurinectes vetulus) from Puget sound, Washington, USA: Relationship with other Biomarkers of contaminant Exposure. Marine Enviromental Research, 45 : (1), 47-67.

Modra, H.; Svobodova, Z. and Kolarova, J., (1998), Comparison of Diferential Leukocyte Counts in Fish of Economic and Indicator Importance. Acta Veterinaria Brno, 67 : (4), 215-226.

Nakatani, K.; Agostinho, A. A.; Baumgartner, G.; Bialetzki, A.; Sanches, P. V.; Makrakis, M. C. and Pavanelli, C. S. (2001), Ordem Characiformes. In: Ovos e Larvas de Peixes de Água Doce: Desenvolvimento e Manual de Identificação. Maringá: UEM. pp. 73-220.

Pavanelli, G. C.; Eiras, J. C. and Takemoto, R. M. (2002), Doenças de Peixes - Profilaxia, Diagnóstico e Tratamento. 2. ed. Maringá: UEM.

Ranzani-Paiva, M. J. T. (1995), Células do sangue periférico e contagem diferencial de leucócitos de tainha Mugil platanus, Gunther,1880 (Osteichtyes, Mugilidae) da região estuarina-lagunar de CananéiaSP ( Lat. 25 $05^{\circ} \mathrm{S}$ - Long. $47^{\circ} 55^{\prime} \mathrm{W}$ ). Boletin Instituto de Pesca, 22 : (1), 23-40.

Ranzani-Paiva, M. J. T.; Salles, F. A.; Eiras, J. C.; Ishikawa, C. M. and Alexandrino, A. C. (1999), Análise hematológica de curimbatá (Prochilodus scrofa), pacu (Piractus mesopotamicus) e tambaqui (Colossoma macropomum) das estações de piscicultura do instituto de pesca. Boletim do Instituto de Pesca, 25, 77-83.

Reichenbach-Klinke, H. H. (1973), Fish patology. T.F.H. Publications Inc. Ltd.

Roberts, R. J. (1989), Fish Pathology. 2. ed. London: Baillière Tindall.

Rodrigues, E. L. and Fanta, E. (1998), Liver histopathology of the fish Brachydanio rerio acute exposure to subletal livels of the organophosphate dimetoato 500. Revista Brasileira de Zoologia, 15, 441-450.

Serpunin, G. G. and Likhatchyova, O. A. (1998), Use of the ichthyohaematological studies in ecological monitoring of the reservoirs. Acta Veterinaria Brno., 67 : (4), 339-345.

Silvano, R. A. M; Oyakawa, O. T.; Amaral, B. D. and Begossi, A. (2001), Peixes do alto rio Juruá (Amazônia, Brasil). São Paulo: Universidade de São Paulo, Imprensa Oficial do Estado, São Paulo.

Vazzoler, A. E. A. M. (1996), Biologia da Reprodução de Peixes Teleósteos. Teoria e Prática. Maringá: EDUEM/SBI. 169 pp. 